\title{
Evidence System of Counting Elements of State Loss Against Corruption Criminal Actions in Indonesian Criminal Jurisdiction System
}

\author{
M. Rizal Bagaskoro ${ }^{*}$ ) and, Jawade Hafidz ${ }^{* *}$ ) \\ *) Student of Master of Law, Faculty of Law, Universitas Islam Sultan Agung \\ Semarang, Email: mrizalbagas@gmail.com \\ **) Lecturer Master of Law, Faculty of Law, Universitas Islam Sultan Agung \\ Semarang.
}

\begin{abstract}
.
This study seeks to answer the problem of what is the legal problem in the process of proving the calculation of elements of the State Financial Loss on Corruption? And what is the solution to legal problems in Evidence of Calculation of Elements of State Financial Losses on Corruption in the Criminal Justice System? Research for is normative research. Based on the research, it can be concluded that the problems of the legal system are related to the substance of the law in law enforcement on corruption which is detrimental to state finances and problems in the legal system related to the legal structure in law enforcement in criminal acts of corruption that are detrimental to state finances.

Keywords: Evidence System; State Losses; Corruption Crime; Criminal Justice System.
\end{abstract}

\section{Introduction}

Calculation of state losses through audits conducted by auditors at the request of investigators, public prosecutors or a panel of judges in the context of law enforcement is a process of evidence in an effort to enforce the law on corruption in the Criminal Justice System. Evidence that can be derived from experts who are asked to audit to calculate state losses in cases of suspected corruption, can be in the form of:

- Letter evidence, namely in the form of an investigative audit report;

- Evidence of expert testimony given before the investigator or in court.

The two pieces of evidence are the same as other evidence as stipulated in the Criminal Procedure Code Article 184 paragraph (1) and are related to the value of state financial losses incurred in the criminal act of corruption suspected of the perpetrator of the criminal act of corruption.

There is a polemic in the definition of state finances and institutions or agencies authorized to calculate state financial losses. One of the elements that must be proven in fulfilling the elements of a criminal offense of corruption that often raises polemics is the element of state loss as stated in the provisions of Article 2 paragraph (1) and Article 3 of Act No. 31 of 1999 Jo. Act No. 20 of 2001 on Corruption Eradication. The proof of calculating the element of state loss is based on an expert calculation which is usually an auditor, but in practice in court there are often differences in perceptions between the public prosecutors and judges, 
even the experts themselves regarding proving the existence of elements of state losses, especially when determining the amount of financial losses country. ${ }^{1}$

To limit the scope of research and discussion of issues in this thesis, the scope and scope of law enforcement activities in proving and calculating the elements of state losses constitute an integral part of activities that are not separate and constitute an integral part in the process of Proving and Counting Elements of State Losses on Corruption in the Indonesian Criminal Justice System. . Evidence and calculation can be seen from the reciprocal relationship between evidence in the framework of calculating state losses and calculating state losses in the framework of proof.

Based on the background description above, the authors formulate the following problems: What are the legal issues in the process of proving the calculation of elements of state financial loss on the crime of corruption? What is the solution to legal problems in Evidence of Counting Elements of State Financial Losses on Corruption in the Criminal Justice System?

\section{Research methods}

Research to support this writing is normative research by examining literature or secondary data. Normative research is a legal research conducted by examining library materials or secondary data. ${ }^{2}$ The specification of this research is descriptive analytical, the type and source of data comes from secondary data which includes primary legal materials, secondary legal materials, and tertiary legal materials. ${ }^{3}$ Based on data sources and normative juridical research approach methods as described above, data analysis that is more appropriate to use in this study is data analysis with a qualitative approach.

\section{Results and Discussion}

\subsection{Legal issues in the Evidence Process, Calculation of Elements of State Financial Losses on Corruption}

The legal system paradigm developed by Lawrence M, Friedman states that law enforcement includes substantive aspects, structural aspects, and legal culture, so law enforcement is strongly influenced by these three aspects. ${ }^{4}$ These three aspects are a series of sub-system processes that are interconnected in a criminal justice system. Legal problems in proving the calculation of state financial losses in criminal acts of corruption that are detrimental to the State's finances in the criminal justice system.

\footnotetext{
${ }^{1}$ Marwan Efendi. (2010). Korupsi dan Pencegaan. PT Timpani Publishing. p.80.

2 Soerjono Soekanto and, Sri Mamudji. (2003). Penelitian Hukum Normatif: Suatu Tinjauan Singkat. Jakarta: PT Raja Grafindo Persada. p.13.

${ }^{3}$ Husein Umar. (2005). Metode Penelitian Untuk Makalah dan Tesis Bisnis. Jakarta: PT Raja Grafindo Persada. p.41.

${ }^{4}$ Kadri Husin and, Budi Rizki Husin. (2016). Sistem Peradilan Pidana Di Indonesia. Jakarta: Sinar Grafika. p.137.
} 


\subsubsection{Legal Substance Sub System}

Law enforcement through a systems approach, namely the criminal justice system is a process of activities that are interrelated and relate to one another in achieving goals. The criminal justice system in law enforcement consists of inseparable sub-systems. The Legal Substance Sub-system in the criminal justice system, especially the criminal act of corruption, is related to the laws and regulations governing law enforcement on corruption, both material law and formal law. ${ }^{5}$

Evidence through the calculation of state financial losses in law enforcement for corruption that is detrimental to state finances after the Constitutional Court decision No. 25 / PUU-XIV / 2016 is an element of offense that must be proven by the public prosecutor. The real and definite value of state losses in law enforcement for corruption that is detrimental to the state will then be used as a basis for punishment, namely the imposition of additional crimes by the Panel of Judges in the form of replacement money. This multiplication money is the money for restitution of state losses caused by the convict's actions which have caused losses to the state finances and is borne by the convicted person, if within a certain time the replacement money has not been paid by the convicted person then confiscated his assets to be auctioned off and if it is insufficient it will be replaced by imprisonment.

The authority to investigate and prosecute criminal acts of corruption that harm state finances in the criminal justice system can be exercised by the Prosecutor's Office and the Corruption Eradication Commission. The Corruption Eradication Commission has the task of coordinating with agencies authorized to eradicate corruption crimes. The definition of authorized agency according to the elucidation of Article 6, Act No.30 of 2002 concerning the Corruption Eradication Commission includes the Financial Audit Board, the Financial and Development Supervisory Agency, the State Administrators Wealth Audit Commission, the Inspectorate of Ministries or Non-Departmental Government Agencies.

The practice of law enforcement on corruption in the criminal justice system prior to Act No.15 of 2006 concerning the Supreme Audit Agency and SEMA 04 / Bua.6 / Hs / SP / XII / 2016 published the evidence of calculating state losses in the context of law enforcement in cases of criminal acts. Corruption crimes that harm state finances are generally carried out by agencies outside the BPK, such as the BPKP and the Inspectorate. These cases have been examined and decided at the court of first instance, at the appeal and cassation level and have permanent legal force. What are the considerations and objectives of the Supreme Court in issuing the SEMA as a guide for judges in deciding cases of corruption that are detrimental to state finances is not explained in the SEMA.

\subsubsection{Legal Structure Sub System}

\footnotetext{
${ }^{5}$ Barda Nawawi Arief. (2012). Kebijakan Formulasi Ketentuan Pidana dalam Peraturan PerundangUndangan. Semarang: Pustaka Magister Semarang. p.11.
} 
The Indonesian Criminal Justice System is normatively regulated in the Criminal Procedure Code, which in its formation is expected to be a codification of law. ${ }^{6}$ The legal structure component carries out law enforcement in the criminal justice system based on the Criminal Procedure Code as formal law or procedural law which serves as a guideline for the state through law enforcement officials to enforce material criminal law. The Criminal Procedure Code as a guideline for criminal law enforcement in the criminal justice system has regulated the relationship between law enforcement institutions, which adhere to a system of specialization, differentiation and compartment. Specialization means the specificity of authority, while differentiation means differentiating the duties and authorities of the examination level from the time of investigation, prosecution and examination at trial, as well as compartments that provide a barrier to the duties and powers of investigators and public prosecutors as well as examinations at trial. ${ }^{7}$

Legal problems can arise in law enforcement for criminal acts of corruption in the criminal justice system with the existence of several institutions that are authorized to carry out investigations, with different procedures and procedures for same object of crime. It cannot be denied that in the practice of criminal law enforcement, it is inseparable from the subjectivity factor of law enforcement officials both in conducting investigations, prosecutorial powers, even in exercising the authority of judicial power in deciding cases. The perceptions and understanding of law enforcement officials on the formulation of not criminal corruption which is detrimental to state finances as stipulated in Article 2 paragraph (1) and Article 3 of Act No.31 of 1999 can be different which results in different imposition of articles in the prosecution resulting in different criminal threats.

There are several patterns of submitting investigation files for corruption cases from the investigation stage to the prosecution stage, namely: 1) Submission of case files from the National Police investigators to the Public Prosecutors at the Prosecutor's Office, 2) Submission of case files from the Prosecutor's Office to the Public Prosecutors at the Prosecutor's Office, 3 ) Submission of case files from the Corruption Eradication Commission investigators to the Public Prosecutor at the Corruption Eradication Commission (KPK) in the Criminal Procedure Code in a differential and potential for abuse of power.Any power that is not aware of its meaning and boundaries will always tempt its holder to behave in an arrogant manner. ${ }^{8}$

\subsection{Solutions to legal problems in Evidence of Counting Elements of State Financial Losses on Corruption in the Criminal Justice System}

Legal problems in law enforcement in criminal acts of corruption that are

\footnotetext{
${ }^{6}$ Luhut. M.P.Pangaribuan. (2006). Hukum Acara Pidana Surat-surat Resmi di Pengadilan. Jakarta: Djambatan.p.1.

${ }^{7}$ R.Widyo Pramono. Op. Cit. p.156.

${ }^{8}$ M.Yahya Harahap. (2006). Pembahasan Permasalahan dan Penerapan KUHAP. Cet. 8. Jakarta: Sinar Grafika. p. 7.
} 
detrimental to state finances in the criminal justice system as described above can be grouped into two parts, namely:

- Problems in the legal system related to the substance of law in law enforcement in criminal acts of corruption that harm state finances, namely:

- the formulation of criminal threats in the material law for law enforcement on corruption is different even though the substance of the offense which is detrimental to state finances in Article 2 paragraph (1) and Article 3 is almost the same;

- The procedures and procedures for the implementation of law enforcement on corruption in the context of criminal responsibility are not the same.

- Legal system problems related to the legal structure in law enforcement in criminal acts of corruption that are detrimental to state finances, namely:

- There are several law enforcement agencies that have the same authority, investigative authority and / or prosecution authority in enforcing the law on criminal acts of corruption;

- The existence of different powers and independence among law enforcement officers.

Legal issues related to the legal substance sub-system state that the formulation of offenses in the material law of corruption is a formal offense, but in practice, corruption is a material offense. Legal issues related to the subsystem of the legal structure, there are several law enforcement institutions that have the authority to investigate and prosecute which according to the Criminal Procedure Code as the operational basis for criminal law enforcement adheres to a system of specialization, differentiation and compartment as well as procedures and procedures for implementing different law enforcement.

The legal system, especially the material legal substance sub-system that regulates the crime of corruption, is not in accordance with the development of incidents of corruption, both from the perspective of the frequency of its occurrence and the quality of corruption. Act No.31 of 1999, in conjunction with Act No. 20 of 2001 as a legal substance sub-system in the criminal law system formulates corruption offenses, especially corruption crimes that harm state finances as regulated in Article 2 paragraph (1) and Article 3 as formal offenses . In practice the implementation of the offense must be proven by the realization of state losses that have actually occurred or can be said to be a material offense. The principle of the material of the law as regulated in Article 5 of Act No. ${ }^{9}$

Efforts to improve legal problems in law enforcement on criminal acts of corruption that are detrimental to state finances and improve the quality of the criminal justice system, namely:

- To reformulate (reformulate) the criminal offense of corruption and the formulation of penalties in the legal substance subsystem, namely Act No.31 of 1999 as amended by Act No. 2 of 2001.

- Adjusting (reorienting) the procedural law of law enforcement on corruption which becomes a common guideline for law enforcement

\footnotetext{
${ }^{9}$ Indonesia. Law on the Formation of Invitational Laws. Act No. 10. LN. No. 53 of 2004, TLN No.4389 article 5 letter $(\mathrm{d})$.
} 
agencies.

- Reorganize (restructure) the subsystem of the legal structure, namely law enforcement institutions that will exercise power.

\section{Closing}

Legal problems that arise in proving the calculation of state financial losses in law enforcement of corruption crimes that harm state finances can be grouped into two parts, namely: Legal system problems related to the substance of law in law enforcement, corruption crimes that harm state finances and legal system problems related to the legal structure in law enforcement in criminal acts of corruption that are detrimental to state finances. The solution to the problem can be done by improving laws relating to both material law and formal law and through institutional improvements through: Reformulation of offenses and formulation of criminal threats of corruption, synchronization and harmonization of statutory regulations. Legislative and Executive Institutions, in this case the House of Representatives and the Government related to the formation of laws, carry out reformulation of offenses and formulations of criminal threats of corruption Act No. 31 of 1999 concerning Eradication of Corruption Crimes as amended by Act No. 20 of 2001 concerning Amendment to Act No. 31 of 1999. Legislative and Executive Institutions, in this case the House of Representatives and the Government which are authorized and involved in the formation of laws make adjustments (reorientation) to the procedural law of criminal law enforcement on corruption which becomes a common guideline for all law enforcement agencies.

\section{References}

\section{Books:}

[1] Barda Nawawi Arief. (2012). Kebijakan Formulasi Ketentuan Pidana dalam Peraturan Perundang-Undangan. Semarang: Pustaka Magister Semarang.

[2] Husein Umar. (2005). Metode Penelitian Untuk Makalah dan Tesis Bisnis. Jakarta: PT Raja Grafindo Persada.

[3] Kadri Husin and, Budi Rizki Husin. (2016). Sistem Peradilan Pidana Di Indonesia. Jakarta: Sinar Grafika.

[4] Luhut. M.P.Pangaribuan. (2006). Hukum Acara Pidana Surat-surat Resmi di Pengadilan. Jakarta: Djambatan.

[5] M.Yahya Harahap. (2006). Pembahasan Permasalahan dan Penerapan KUHAP. Cet. 8. Jakarta: Sinar Grafika.

[6] Marwan Efendi. (2010). Korupsi dan Pencegaan. PT Timpani Publishing.

[7] Soerjono Soekanto and, Sri Mamudji. (2003). Penelitian Hukum Normatif: Suatu Tinjauan Singkat. Jakarta: PT RajaGrafindo Persada.

\section{Regulations:}

[1] Act No.8 of 1981 concerning Criminal Procedure Law

[2] Act No.31 of 1999 on Corruption Eradication 
ISSN : 2747-2604

Volume 2 Issue 4, December 2020, (619-625)

[3] Act No. 17 of 2003 concerning State Finances

[4] Act No.1 of 2004 concerning State Treasury

[5] Corruption Court Decision 